\title{
Power balances, transnational elites, and local economic governance: the political economy of development in Medellín
}

\begin{abstract}
Applying a non-linear political economy analysis of power balances, institutional mechanisms, and elite structures, this study sheds light on the characteristics of Medellín’s economic development since the early 2000s. Elites with minimal technological capabilities and interests in promoting the advancement of transnational capitalism have successfully secured access to sources of power. These conditions (re)produce neoliberal logics of local governance that focus on economic growth in sectors with perceived global comparative advantages and on sustaining the particular power balances in Medellín's political settlement. This has led to failures of generating positive forward and backward linkages for productivity growth of local firms, a local labour market marked by low wages and high employment elasticities, and large income inequalities. The local governance model that perpetuates productivity and inequality problems of the city is adopted as an opportunistic discourse of Medellín's transnationalised capitalist elite in the larger neoliberal context of Colombia's polity and economic policy agenda. In the absence of structural reforms targeting low wages and incentivising firms to develop technological capabilities, Medellín’s low productivity and high inequality problems are likely to persist.
\end{abstract}

\section{Introduction}

In the 1980s and early 1990s, Colombia’s second city Medellín became famous for being the 'most violent city in the world', as the Medellín Cartel brought terror to the streets of the city. Led by Pablo Escobar, the Cartel questioned the political and economic legitimacy of local institutions and the predominant power balances. Following the introduction of neoliberal reforms in Colombia during 1990s, what Hirschman (1981: 155) coined fracasomania - an obsession with seeing everything that preceded as a complete failure -, Medellín’s political economy recovered very slowly. With a severe economic and financial crisis hitting Colombia at the turn of the millennium, the economic and political viability of the city’s developmental trajectory remained fragile: Medellín’s violence rates continued to be high, the local economy experienced a recession with negative growth rates of around $5 \%$, and the urban unemployment rate rose over $20 \%$. 
However, between 2003 and 2014 growth of Medellín’s per capita gross domestic product (GDP) surpassed the average growth rate of Colombia's economy by large margins. In 2014 Medellín’s GDP per capita grew by over 4.2\%, making the city’s economy the fastest growing urban market in Latin America (Brookings, 2015). The truly remarkable success story of Medellín has recently been the subject of many scholarly and non-academic analyses. Most contributions come to the conclusion that the city's development is nothing short of a 'miracle' for which the introduction of the 'right' institutional structures and 'good' governance reforms are responsible (see Bahl, 2012; Devlin and Chaskel, 2010; Gutiérrez et al., 2013; Maclean, 2014). In his article in this journal, Ivan Turok (2014: 557-8) finds that local leaders’ 'deep commitment to social transformation... backed by investment in building organisational capacity, both within the public sector and among non-governmental organisations and social movements' lie at the heart of Medellín’s transformation.

However, and different from existing academic analyses of Medellín’s transformation, this article studies the historically evolved distribution of power, local institutional changes, and elite interests to understand the dynamics behind the city's economic development. As such, this paper explores the explanatory value of the so-called political settlements literature. Pioneered by Mushtaq Khan (1995), the political settlements framework is a critical analytical political economy approach arguing that there are no 'good' or 'bad' institutions to achieve development. Rather, developmental outcomes depend on the particular political settlement, which describes 'a combination of power and institutions that is mutually compatible and also sustainable in terms of economic and political viability' (Khan, 2010: 4). 
Applying this political settlements framework to the analysis of elite structures, power balances and the formal and informal institutional mechanisms, this study sheds light on the particular characteristics of Medellín’s development since the early 2000s. The introduction of neoliberal reforms in Colombia meant that traditional sources of income and power were increasingly phased out (i.e. with the abolishment of subsidised industrial credits). The resulting weakening of the traditional oligarchic industrial elite and the emergence of a political class with access to alternative sources of power (i.e. the illicit drug economy) led to political and economic instability. Nevertheless, during the implementation of structural adjustment reforms in the 1990s, the traditional elite could influence institutional mechanisms linked to the creation of new income opportunities (i.e. through privatisation and deregulation of specific sectors). Besides these changes in sources of power, the transition from an inward-oriented developmental model to a liberalised economic system also implied shifts in elite interests and capabilities towards a transnational logic of capital accumulation.

\section{Of power, institutions, and elites: the political settlements framework}

Political economy theories on why some countries are successful while others fail in achieving development largely emphasise the importance of power relations. Most prominently, Acemoglu and Robinson (2012) find that 'nations fail' due to unfavourable power balances that slow down or hinder the emergence of institutions that can protect private property rights and increase governance accountability. In most political economy discussions about the factors influencing the operation and the development outcomes of a political system, much attention is paid to the role of vested interests of elite factions in influencing institutional performance. Acemoglu and Robinson (2012) argue that the 
persistence of 'wrong' governance structures in less developed countries is a result of the ways in which powerful elites use political systems for the appropriation of rents that would disappear with 'right' institutional arrangements. Similarly, Kauffman et al. (1999), Krueger (1974), and Rodrik (1995) find that inefficient institutional regulations persist due to politically and economically powerful business groups and elites who use quotas, subsidies and tariffs to redistribute incomes to themselves. For this strand of literature, which originates from discussions in New Institutional Economics (NIE), the failure to achieve development is rooted in the failure to create and maintain stable, well-protected property rights, rule of law, and low corruption (Acemoglu et al., 2004; Acemoglu and Robinson, 2013; Kauffman et al., 1999; Krueger, 1974). The main argument is that powerful elites who are interested in the maximisation of their material gains obstruct growth-enhancing institutional changes.

By contrast, the so-called political settlements framework, a critical political economy analytical approach pioneered by Khan (1995), argues that there are no 'good' or 'bad' institutions, but only favourable and less favourable interdependent combinations of power balances and institutions. A political settlement is 'a combination of power and institutions that is mutually compatible and also sustainable in terms of economic and political viability' (Khan, 2010: 4). The political settlements framework is rooted in the idea that the historically evolved distribution of power interdependently shapes the institutional context in which policies are implemented in order to achieve development. Power is understood not only as economic capacities, but also includes considerations 'how the relative power of organisations in that society affects the enforceability of different institutional rules' (Khan, 2011: 1). This understanding of power includes the analysis of capacities of groups and classes to mobilise against imposed costs (i.e. through 
demonstrations) and to absorb pain (Khan, 2009: 55). This notion of power facilitates the analysis of elites, powerful groups, and subordinate classes not solely according to their economic power, but also in terms of their political, organisational, and ideological capabilities.

An important dimension in the political settlements theory is the source of power. A key research question is thus, how the political settlements have been - and continue to be - financed. The relative power of particular economic groups vis-à-vis the state is a crucial aspect of studying how power is achieved and maintained, as this relationship determines the type of institutions that distribute benefits in order to maintain predominant power balances (see Abdulai, 2017). Entrepreneurial capabilities and sectoral activities of the economic actors and elites as well as the ownership structure of their firms can give important insights into their (political) interests and bargaining games in a political settlement (Di John and Putzel, 2009). However, and since many capitalist and noncapitalist firms often operate in multiple sectors, it is advisable to look at the historical evolvement of their capabilities and their relative organisational power in a political settlement (Pospisil and Rocha Menocal, 2017).

Analysing the historically evolved relative power of economic groups and their capabilities in different sectors can give insights into elite influence on governance agencies (i.e. ruling coalition) in the distribution of benefits. This is true for the access to both, industrial financing instruments in pre-liberalisation contexts as well as benefits and priorities during liberalisation and privatisation reforms. For example, during import substitution industrialisation (ISI), elites in Latin America were able to influence institutional mechanisms that guaranteed access to benefits for their industrial activities (i.e. subsidised credits). This did not only help to achieve easy industrialisation, but also 
consolidated power of the oligarchic elites in countries such as Colombia, Brazil, or Peru (see Khan and Blankenburg, 2009).

Violence is another important source of power in a political settlement. Violence needs to be understood firstly as the act of establishing violence, often through the appropriation of assets and accumulation by dispossession (Harvey, 2003), as well as the fight over the consolidation of this monopoly (Giustozzi, 2011). The reoccurring phenomenon of military dictatorships in Latin America throughout the twentieth century and the continued prominence of primitive accumulation and (urban) land grabs underline the importance of violence as an important source of power (Biglaiser, 2002; Gómez et al., 2015; Loveman, 1999; Steel et al., 2017).

In most local contexts of the Global South today, power is often not fully aligned with the formal capitalist institutions and instead depends on informal institutional mechanisms (see Behuria et al., 2017). Firstly, this makes the mimicking of institutional policies of advanced capitalist settings difficult. Secondly, this means that changes in the distribution of power in local settings of less developed countries are not necessarily a result of changes in formal institutions, but rather in informal ones. Khan (2010: 10) defines informal institutions as 'patterns of behaviour of individuals who are following internalised norms and values...(and) rules that are not formally written down...but which are nevertheless enforced by third parties’ such as patronage structures, mafias, or patronclient networks. Illicit flows and accumulation patterns are thus a crucial aspect in the analysis of the distribution of power across a political settlement, particularly in Latin America (see Alonso et al., 2007; Ballvé, 2013; Romero and Valencia, 2007; Vargas, 2011; Watt and Zepeda, 2012). 
Besides these factors that are internal to a particular society, exogenous factors that can influence the interdependent relationships between power and institutions and their indeterminate development outcomes need to be considered (see Hambleton, 2015; Rodrik, 2014). This includes global economic and financial crises, shifts in international development paradigms and ideologies, current national policies, and capitalist transnationalisation.

The analysis of exogenous factors is particularly relevant for the study of Latin American societies, where external debt has generally been very high. For example, paradigm shifts in international development organisations have played a crucial role in shaping elite interests and policy choices of political actors in Latin America are (see Glassman and Carmody, 2001). This is particularly true for the shift towards the so-called 'Washington Consensus’, where Williamson (1990) argued that Latin America’s policy makers should inter alia introduce reforms packages to privatise state-owned enterprises, to introduce fiscal policy discipline, and to liberalise fiscal and currant accounts. Furthermore, the recommendations of the 'post-Washington Consensus' (see Stiglitz, 1998) particularly targeted Latin American countries where the market-based policies had failed to achieve considerable levels of economic development.

Furthermore, recent developments in local settings of less developed countries need to be understood in the context of broader shifts in capitalist development. The global economic integration of Latin America's economies implied the transnationalisation of local capitalist assets and elite interests. Latin America’s local contingents of transnational capitalists have consolidated their economic power by developing capacities as political actors through '(establishing) new institutional bases from which to develop programs and assemble teams, largely constituted by new private sector associations and elite 
foundations' (Robinson, 2010: 173). This also included 'a shift in subsidies that states provide, away from social reproduction and from internal economic agents and towards transnational capital’ (Robinson, 2010: 33). While the transnational capitalist elite in local contexts of Latin American societies might be qualitatively different from the well-paid junior partners of imperialist capital, it has many of its origins in the old-style comprador class (see Reyes, 2003).

Hambleton (2015) also finds that powerful globalised actors shape the context in which place-based local policies are introduced and enforced. However, the author argues that 'cities and localities are not helpless victims in a global flow of events' (Hambleton, 2015: 172). The task for local governance actors and institutions is to manage the external pressures in ways that bring positive outcomes for the local population. The local contingents of Latin America’s transnationalised capitalists, for example, play a key role in the internalisation of external dynamics and interests and need to be understood as such. A key challenge for scholars researching local governance in globalised contexts is thus to identify external powerful forces as well as local 'place-based' actors that negotiate with globalised organisations, internalise and indigenise external interests, and implement and enforce local economic policies.

With these theoretical considerations in mind, the next sections discuss the development of Colombia’s second city Medellín. The detailed analysis of historically evolved power balances, external influences, and interests of local actors provides in-depth explanations of recent economic changes in Medellín that go beyond the dominant ‘miracle’ arguments. 


\section{The historical evolution of power, institutions and elite interests in Medellín}

The main variable of the political settlements approach is the historically evolved distribution of power in a particular society. As such, the study of Medellín’s development requires an analysis of the power balances that shape the local context. While historically, Medellín’s society had been characterised by a strong hegemony of oligarchic economic elites with entrepreneurial capabilities in labour-intensive industrial sectors, such as textiles, this changed during the course of the 1980s and 1990s.

With Colombia’s industrial decline in the late-1970s, Medellín’s elite and the entire urban economy 'stood at the advent of an irreversible crisis in the productive sector, which witnessed the beginning of the decline of hegemony and the reorganisation of the industrial elite (in Medellín)’ (Franco Restrepo, 2005: 154). The deindustrialisation started with the crisis of the textile industry (Escobar and Hoyos, 1986) and symbolised a decrease in the elite's access to traditional sources of their power in form of state-created industrial benefits (i.e. tariffs and subsidies for light manufacturing industries).

With these changes, the dominant economic elite was challenged by the rise of 'a new elite, a political class, which was formed around a regional bureaucratic apparatus’ (Dover and Ocampo, 2006: 263-264). Professional politicians, who articulated their interests independently from the traditional elites, started a process of reorganisation of power relations (Duque Daza, 2007). Duncan (2005) and Palacios (2001) find the rise of the political emerging class ('clase emergente') a logical consequence of a crisis of the ISI development model which had been the main source of power for the traditional economic elites leading to 'a fragmentation of the elite - in singular - into different groups of power' (Leyva, 2014: 126). Many observers consider this the breaking point between the political 
and economic elites in Medellín (see Dover and Ocampo, 2006; Franco Restrepo, 2005; Restrepo Santamaría, 2011).

The rise of the ‘emergentes’ also meant an increasing competition over economic influence in order to secure access to sources of power (Franco Restrepo, 2005: 355). For example, the 'emergentes' developed links with actors of the illicit drug industry, namely Pablo Escobar and his Medellín Cartel and paramilitary groups, which are well documented elsewhere $^{1}$ (see Carvajal, 2011; Duncan, 2013; Martin, 2014; Romero and Valencia, 2007; Salazar, 1990, 2012; Thoumi, 1995). Moreover, the emerging political class also developed capabilities in sectors that had been traditionally in the sphere of influence of the oligarchic economic elite (see Franco Restrepo, 2005; Leyva, 2014; Restrepo Santamaría, 2011). As a response to this threat from outsiders of the dominant elite bargain and a continued decline of industrial incomes that resulted in hostile takeovers of some of Medellín’s flagship companies by rival elite factions (see Londoño, 2004; Restrepo Santamaría, 2011), Medellín’s traditional elites formed the so-called Sindicato Antioqueño also known as Grupo Empresarial Antioqueño (Entrepreneurial Group of Antioquia, GEA)².

Various other factors in the 1990s such as far-reaching liberalisation, drastic privatisation, extensive deregulation and decentralisation ${ }^{3}$ reforms, as well as economic and financial crises changed the context in which the different elite factions tried to (formally and informally) influence the institutional landscape in order to secure access to sources of power. This also influenced the interests of the different elite factions.

\section{From a closed to a liberalised economy: power, institutions, and elites in Medellín}

The decrease of internal demand caused by the crises of Colombia’s inward-oriented developmental model, and the decline in foreign demand caused by the massive 1980s debt 
crises of many Latin American countries had detrimental effects on Colombia's current account. Following the large increase in deficit during the 1980s, Colombia 'started a process of structural adjustment, which did not only include an orthodox macroeconomic program, overlooked by the International Monetary Fund (IMF), but also an interference of the World Bank, particularly in sectoral politics' (Ocampo, 1986: 230). This intervention of international organizations not only led to the reversal of many of Colombia's protectionist measures (see López Restrepo, 1995), but has also substantially limited policy control of local and national governance agencies.

The 1991 Colombian Constitution completely liberalised the country's current and capital accounts (Ocampo, 2007). Better known today as 'apertura' (opening), this also entailed a sweeping privatisation of public assets and services, extensive deregulation of state control over productive sectors, the introduction of a new foreign investment regime, the flexibilisation of labour markets, and a drastic devaluation of the Colombian Peso (Garay, 1998). The idea behind the restructuring efforts was to minimise the role of the state and its capacity to intervene in economic policy in order to secure and guarantee free market competition (see Constitución Política de Colombia, 1991, articles 333 and 334).

For Medellín's elites, this meant that access to traditional sources of state-created industrial rents diminished (i.e. through subsidised credits), changing the formal and informal activities regarding elite access to new sources of power. During the implementation of the 'apertura' reforms powerful business groups, inter alia the GEA, could influence institutional mechanisms linked to the creation of new income opportunities (i.e. through privatisation and deregulation of specific sectors). Business groups with traditionally large organisational power, such as the GEA became 'the most 
consistent beneficiaries of some of the reforms' central programs, especially privatisation’ (Rettberg, 2005: 33).

As traditional accumulation strategies were no longer viable, Medellín’s economic elite focused on developing entrepreneurial and technological capabilities in sectors that were believed to have comparative advantages in global value creation (see Fernández Jilberto and Hogenboom, 2004: 154). The GEA used the neoliberal turn of Colombia to deepen capital concentration in the sectors of finance, services, construction, and food processing.

In interviews with several CEOs of GEA companies, it was repeatedly stressed that in order to be competitive in the global markets the GEA needed to concentrate on economic activities in sectors where Medellín has comparative advantages over other cities with similar factor endowments. Ricardo Sierra, longstanding CEO of the GEA confirmed that 'with the 'apertura' all of the companies started to have different problems... than in the closed economy of the 1970s’ (Sierra, 2014). The current CEO of the GEA's largest insurance company Sura emphasised that in the liberalised companies 'needed to disinvest in traditional businesses to be able to invest in finance, cement, and light manufacturing because we knew we had to go out and compete not only in Colombia but also outside’ (Bojanini, 2014). José Alberto Vélez, CEO of Argos, Colombia’s largest construction material producer, confirmed this: 'we had to diversify geographically and each company should concentrate on a single sector... With this strategy we gained increased capacity to indebt our companies ${ }^{4 ،}$ (Vélez, 2014).

This increased capacity to raise external funding also stems from a change in the organisation of the GEA in Colombia's financially liberalised economy. Holding companies were formed in order to secure access to new financial resources through 
increased participation in international credit markets. The rationale for this concentration on financial activities is the fact that financial intermediation 'does not require high levels of capital investment but generates capital gains’ (Sierra, 2014). Ricardo Sierra further stressed that 'the GEA's companies redefine their businesses within (the context of) globalisation; and with globalisation they needed to become Multilatinas,' (Sierra, 2014).

The transition towards a transnational capitalist elite reflects a broader trend of elites in less developing countries aiming at the promotion of the advancement of financialised global capitalism (see Reyes, 2003; Robinson, 2010). Globalised financial circuits have dictated the strategy of the GEA since the 'apertura’ reforms, making activities linked to sectors such as finance, real estate, tourism, and construction the primary sources of profit and power.

Besides these changes in sources of power linked to shifts from an inward-oriented developmental model towards a neoliberal logic of transnational capital accumulation (which also implied changes on the organisational structures of Medellín’s businesses), there remain some local government incomes that need to be considered in the analysis of the different sources of power and elite interests. The next subsection discusses how the local public utility provider EPM is an important factor in the analysis of sources of power in Medellín’s political settlement following the ‘apertura’ reforms.

\section{Empresas Públicas de Medellín (EPM), elite disputes, and power balances}

Despite that EPM is governed by private law (known as 'privatismo organizacional' see Varela Barrios, 2011, 2010), ownership of the company remains fully public. EPM continues to transfer $30 \%$ of its dividends to the municipal budget, making the company an 
important mechanism for the creation of additional income (Botero and Villegas, 2005; López, 2005).

While the access to public incomes through EPM had always been attractive for local elite factions, the control of EPM became a particular interest following the 'apertura' and several reform changes allowing EPM to access the international credit market, debt finance its operations, and create for-profit joint venture companies in other regions (see Furlong, 2015). This provided opportunities for public administrations to circumvent constitutional limitations on debt finance for municipalities (Cabrera and Naranjo, 2003), making EPM an important source of incomes through increased transfers to the municipality budget (see figure 1 and figure 2) and contracting for infrastructural projects. Drawing on urban entrepreneurialism literature, Furlong (2015: 202) argues that the increase in the company’s capacity to transfer additional income to the municipality's budget is an indicator that in Medellín 'capitalist production is enmeshed with public dividends and social reproduction’. The capacity of EPM to create large amounts of additional incomes has made the public utility company an important source of power. According to Dover and Ocampo (2006: 286) EPM has become 'politically attractive, due to its symbolic capital... as well as due to its transferred financial resources to the Mayor's office’. 


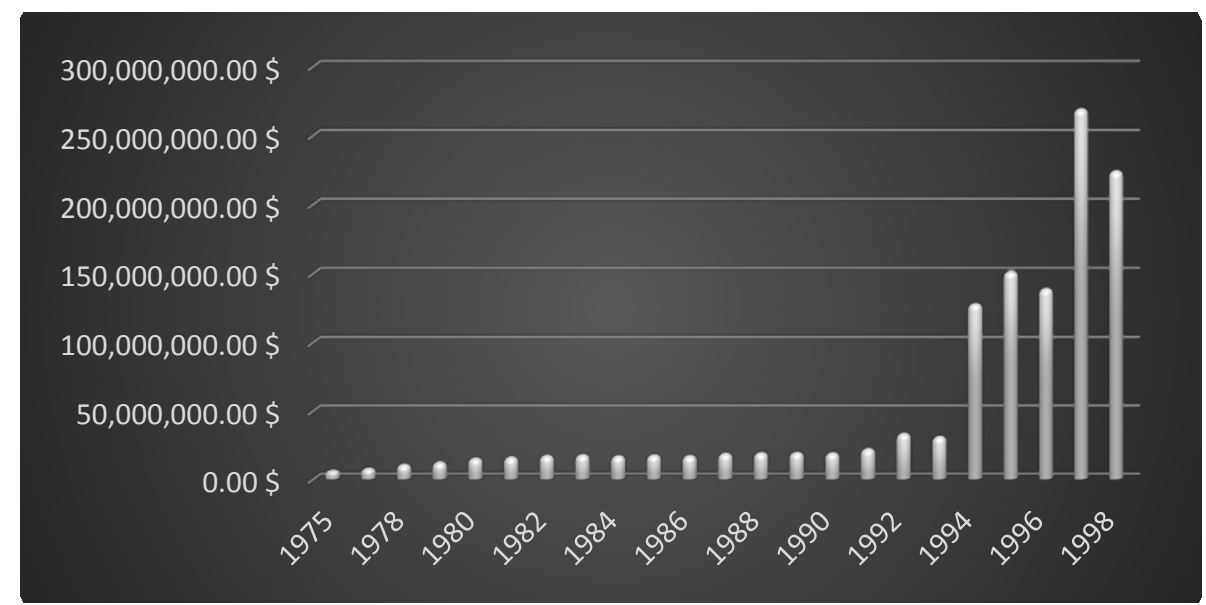

FIGURE 1: TRANSFERS FROM EPM TO THE MUNICIPAL BUDGET IN CURRENT COP SOURCES: BONILLA ET AL. (2013); BONILLA AND AMADO (2013); CARRANZA AND BONILLA (2013)

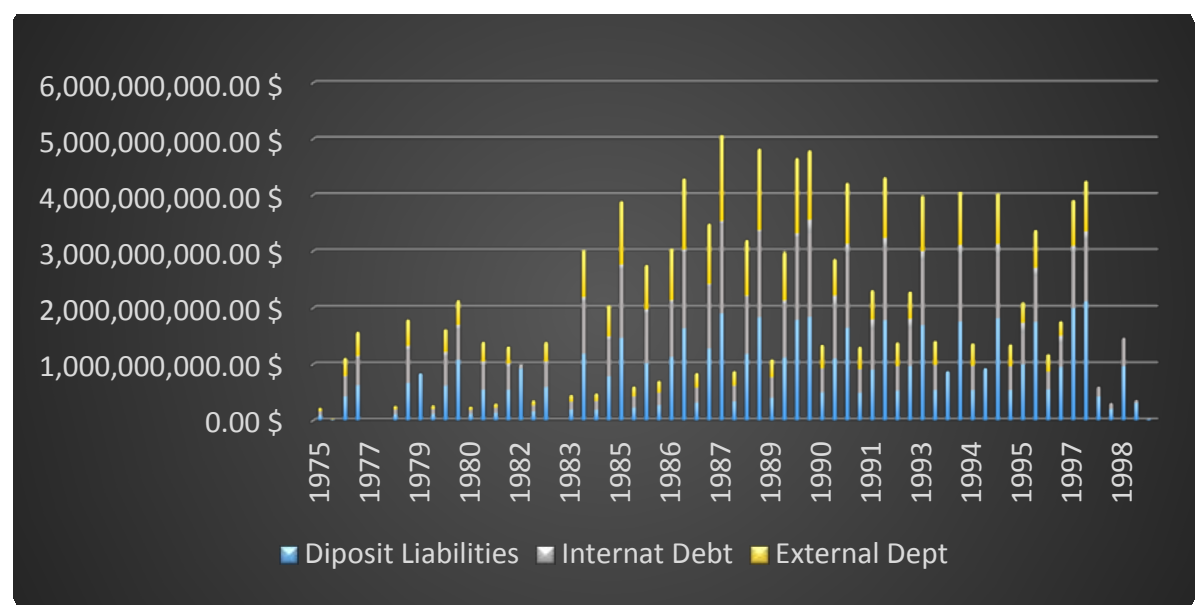

FiguRE 2: ACCUMULATED DEBT OF EPM IN CURRENT COP

SOURCES: BONILLA ET AL. (2013); BONILLA AND AMADO (2013); CARRANZA AND BONILLA (2013)

The victory of Luis Pérez Gutiérrez in the 2000 mayoral elections marks an important point in the history of Medellín’s elites and their dispute over access to sources of power. Pérez Gutiérrez is one of the leading representatives of the political class of 'emergentes'.

Following his election, the competition over access to EPM's profits became a source of tensions between the economic elite of the GEA and the political class of 'emergentes'. 
Self-declared as 'the real representative of the people' who was against the ‘exclusionary tradition of the economic elites’, Mayor Pérez Gutiérrez adopted a confrontational discourse towards the economic elites of the GEA (see Dover and Ocampo, 2006: 268-270). In his first year in office, Mayor Pérez Gutiérrez declared that 'EPM controls most business in Colombia... The GEA is pennyworth compared... and this is what makes it attractive for the people of the GEA who want to take over EPM' (Dover and Ocampo, 2006: 254).

Policies causing conflict between the different elite factions were inter alia the expansion of EPM into sectors beyond gas, water and electricity (also into GEA-controlled sectors) as well as the introduction of so-called 'tarifas justas', fair tariffs that aimed to freeze energy and water prices (Pérez Gutiérrez, 2003). Members of the economic elite saw this as a frontal attack on their interests. Dover and Ocampo (2006: 286) conclude the elite disputes over EPM that caused political fragility are 'consequences from the way Pérez Gutiérrez rejected the economic leadership of the city and favoured the political management of the company'. The marginalisation of the GEA in the ruling coalition and the exclusion from access to local government incomes destabilised the polity at the turn of the millennium (Franco Restrepo, 2005: 29). Relationships between the GEA and Pérez Gutiérrez remain sour to this day, demonstrated by Ricardo Sierra’s (the longstanding CEO of the GEA) view on this: 'I hate Luis Pérez, because we know that he is a rat and that he is a thief' (Sierra, 2014).

Based on interviews with members of the political and the economic elites, Betancur et al. (2001) confirm this divide between the two elite factions after the turn of the millennium. Thus, despite the GEA representatives stressing that 'we need to work together to help each other', the interviews show growing gaps between the factions. One CEO of a 
GEA company mentions that 'the political class is considered as corrupt' and 'the economic class is more representative of the region'. The economic elite saw itself to be 'on a different side', as it supposedly 'integrates more social sectors of society' than the political elite (Betancur et al., 2001: 236).

This idea that the political elite was inherently corrupt and an obstacle to development is not only central in considerations regarding the divide between different powerful elite factions and the destabilisation of the political settlement in Medellín. It also serves as theoretical advocacy for neoliberal governance policies more generally (see Khan, 2012). Furthermore, the rhetoric used by the GEA representative shows that the GEA was mobilising to more actively take control over organisational and distributional powers in Medellín. Betancur et al. (2001: 151) rightly conclude that the shift in the GEA’s strategy 'could be hinting at an interest of the Grupo for more direct involvement in policy decisions in the region'. The next section discusses how the GEA developed capacities of direct political involvement, using a comparative advantage and corruption discourse reflected in proposals of a new governance model for Medellín.

\section{The Medellín model of governance and the role of the GEA}

As discussed, the descendants of the historically dominant elite factions, now represented by the transnational capitalists of the GEA, were increasingly excluded from access to sources of power in form of benefits and transfers from EPM. Consequently, and confronted with changing power structures in a political settlement marked by high competition between different elites, low economic growth, and political instability, the GEA became increasingly interested in establishing a more direct influence in the local political sphere (see Dover and Ocampo, 2006: 256). The economic elite, according to 
GEA affiliate Sergio Fajardo hence 'realised that politicians are the ones who make important decisions in society whether we like it or not, so we said to ourselves that we have to get into politics. Instead of saying how things should be, we said this is the way it is done’ (Fajardo cited in Fukuyama and Colby, 2011).

The Medellín Chamber of Commerce has been an important arena for the GEA’s development of political capacities vis-à-vis the political class of 'emergentes'. Throughout the 1990s, the GEA used the Chamber as an indirect forum of influence to express concerns about the need for policies to facilitate Medellín’s insertion into global value and production chains. In its 1995 'Reporte Monitor’ the Chamber proposed 'strategies such as the change of the productive profile of the region from its traditional industrial setting towards promoting financial, touristic, and medical services’ (Betancur et al., 2001: 138; Cámera de Comercio, 1995). The 1999 ‘Plan Estratégico’ advocated further local economic reforms and promoted the development of sectors that were seen as most likely to compete globally with other similarly endowed cities and stressed that a new form of politics was required that departed from the 'clase emergente' and its 'political-clientelist' way of governance (Cámera de Comercio, 1999).

Hence, with the political understanding that a minimally interventionist state and the conviction that focusing on global comparative advantages achieves optimal outcomes the GEA mobilised to influence Medellín’s Mayoral race in 2003. While in the 1990s the GEA had tentatively begun to develop political capacities to influence municipal political decision making, it was Sergio Fajardo’s Compromiso Ciudadano (Citizens’ Commitment) ${ }^{5}$ and the GEA's strong position in this coalition that cemented the leading role of Medellín’s transnational capitalist elite in the local political arena. Fajardo, former director of the GEA think-tank ProAntioquia and member of a leading 'GEA family' investing in the 
construction sector had helped this new political movement to emerge amidst the political and economic reorganisation of the GEA during the years of the Pérez Gutiérrez administration.

Once in power, the Fajardo coalition implemented an ambitious reform agenda. Their 2004-2007 Development Plan emphasised the need for a reform of public institutions to achieve ‘transparency and good governance’ (Alcaldía de Medellín, 2004: 41), focusing on 'fighting corruption and politicking... to achieve confidence... through transparency and institutional developments... that attract and congregates investments and economic activities (for development)’ (Alcaldía de Medellín, 2004: 15; 99). The agenda was based on the idea that efficient public management needs as little state intervention as possible to avoid any market distortions and restrictions on private capital movements (see Ramírez Brouchoud, 2012).

Another key factor that shaped the governance structure of the Fajardo coalition was the large presence of GEA actors in the cabinet itself as well as in many public-private partnerships created during the first months of the Fajardo government. Fajardo's Private Secretary and campaign manager David Escobar Arango mentioned, 'the interesting part of our governance formula is the public-private spirit. We created new public-private partnerships organisations and institutions after I took office’ (Escobar Arango, 2014).

Various public-private alliances dominate much of Medellín’s new governance framework. A prime example of the increased presence of public-private partnerships in the Fajardo government is the Agencia para la Cooperación Internacional de Medellín (Agency for Cooperation and Investment of Medellín, ACI), which serves to promote Medellín as an attractive destination for Foreign Direct Investments (FDI). According to its former director, Juan David Valderrama, the ACI acts as official organisation 'in all public policy 
areas concerned with social and economic issues.... We want to incentivise and motivate foreign companies to invest in sectors... that focus on services’ (Valderrama, 2014).

The increased influence of private interests in the management of public policy areas is also well reflected in the interviews with CEOs of GEA companies. The current head of the GEA and president of its largest company Sura mentioned the increased power of the GEA:

'the beauty of this created institutionality has been that the government has invited the private actors so we can help in the public management. We are in governing boards, and we hold patronage in many institutions... But if in the future a Mayor will be elected who is against all this, we will put great pressure on him through all the institutions that the city has, first so he won't steal money, and conducts transparent public management, and then apply all the regulatory measures we have set up’ (Bojanini, 2014).

José Alberto Vélez, CEO of Argos added: 'the boards of directors (of public institutions) are very much dominated by the GEA. This makes it possible to keep political partisan clientelism out' (Vélez, 2014). The vice-president of GEA’s Bancolombia also stressed that:

'the creation of public-private alliances and other public institutional penetration from the private sector have secured the continuity of our interests regardless who will come to power... The GEA can act within the margins of the law... and we have been concerned with supporting who we think would govern best... We will not accept a Mayor that de-links us from our political interests again’ (Pérez Moreno, 2014). 
By acquiring detailed legislative and executive capacities, the GEA has great influence on the creation and enforcement of institutional mechanisms and thus sources of additional income and power. While public-private partnerships can be of high importance for productive economic transformation if they build linkages to the wider economy (Jessop and Sum, 2000: 2293), the success in achieving sustainable and inclusive developmental outcomes depends on the wider politico-economic environment, and on the power balances between different actors of a political settlement. And as some academic observers have pointed out, the particularity of Medellín’s political economy has resulted in a shift away from direct intervention of government and state power towards a governance framework that facilitates market-driven management of the local economy (Brand, 2013; Franz, 2017; Hylton, 2007).

Analysing the second 2008-2011 Development Plan of the Fajardo coalition shows that the policies proposed largely focused on strengthening economic sectors with low technological and low productivity potentials (Alcaldía de Medellín, 2008). For example, the 'Medellín Ciudad Cluster' program is aimed at the low productivity sectors of Medellín’s economy ‘in order to achieve a better insertion into global dynamics’ (Alcaldía de Medellín, 2008: 119). This cluster program focuses on Medellín’s ‘local-level competition with other cities and regions for the deployment of economic activities to have the capacity to act in a context of increasing globalisation, creating locational advantages to increase the business climate’ (Alcaldía de Medellín, 2008: 82).

Medellín’s governance agenda fully embraces wider economic ideas and ideals according to which economic growth is based on the city’s global comparative advantages in service sectors, finance, tourism, and construction. In an interview, Fajardo’s successor as Mayor and his close ally Alonso Salazar stressed that 'Medellín is no longer an industrial 
city and is developing as a city of services’ (Salazar, 2014). Iván Mauricio Pérez Salazar, former Secretary of Finance, reaffirms that ‘services are, without a doubt, Medellín’s vocation. We have very strong and competitive service sectors, such as retail, hotels, finance, which for me are the drivers of Medellín’s economy’ (Pérez Salazar, 2014). Fajardo’s Private Secretary and campaign manager highlighted that:

'for Medellín there is no other way (to develop) than through services and this becomes more evident when you look at what is happening in other cities... It is not that we don't want diversification... but I believe what Ricardo Hausmann says is true: 'Rich countries produce rich-country goods'. It sounds silly, but it is true. Here (in Medellín), there will be no exports in steel or cars’ (Escobar Arango, 2014).

The governance model is hence a result of the embeddedness of neoliberal ideology into the urban context of Medellín (see Brenner and Theodore, 2002; Franz, 2017). A manual by the discussed public-private organisation ACI that aims to attract FDI to the city’s economy indicates this rather well:

'The minimum wage in Colombia is one of the lowest in Latin America... Colombia has one of the most flexible labour regimes in Latin America... A day shift [in Medellín] is long, from 6am to 10pm, and the employer can sign on two shifts without overtime pay or night surcharges; in the recruitment and employment of apprentices... the employer has no obligation to pay social benefits,... and the amount of compensation for unreasonable dismissal is very low (ACI et al., 2006: 65-66 cited in Betancur, 2008: 1).

A statement by Fajardo’s Secretary of Social Development also reflects this: 'To strengthen the service sectors the city was given the task of selling itself abroad as a competitive, innovative, affordable city for foreign investment’ (Mejía Martínez, 2014). 
The implementation of Fajardo's governance model is thus an institutional mechanism for market-driven development. The GEA, who prior to economic liberalisation had failed to develop economic capabilities in technologically advanced sectors and concentrated on investments in services following the 'apertura' reforms, gained considerable organisational power following the 2003 municipal elections. Medellín’s transnationalising capitalist elite adopted the neoliberal governance discourse of comparative advantages and corruption as an opportunity to restore and deepen power through securing access to transnational capital as well as sources of locally created benefits by EPM.

The particular distribution of power in Medellín’s political settlement, where transnational capitalist elites with capabilities in firms with minimal technological inventory have considerable power, has resulted in the establishment of institutional mechanisms that enhance conditions in which governance reforms and policy strategies are inherently targeting sectors that are unlikely to be sustainable and inclusive development escalators in the long run. The focus on sectors with perceived global comparative advantages can lead to a failure of attracting FDI that can have positive forward and backward linkages for local medium or high technology sectors and local firms. The extent to which this strategy has driven the development of economic activities will be quantitatively analysed in the following section.

\section{Empirical evaluation}

The political settlements literature argues that developmental outcomes are a reflection of the way in which the distribution of power in a particular setting shapes institutional functions to minimise transaction costs and to distribute benefits according to the 
predominant power balances. The relative power, the capabilities, and the interests of economic groups in this context further influence institutional capacities.

The preceding sections found that the distribution of power in Medellín has led to the establishment of institutional mechanisms that reflect the interests of the GEA. As such, the quantitative evaluation of Medellín’s development outcomes are not presented as isolated results detached from local, context-specific politics. Rather, the capabilities of the GEA and the local governance agenda implemented since 2003 have resulted in the creation and enforcement of institutional mechanisms that drive economic development outcomes and help in maintaining the predominant distribution of power stable.

Between 2004 and 2012 Medellín’s economy grew rapidly, considerably above the average growth rate of Colombia. Some academic observers, NGOs, public officials and business actors in Medellín see this this increased economic dynamic as a result of the 2004 implemented governance agenda, underpinning the 'metropolitan miracle’ (see Cámera de Comercio, 2011). Hence, the aggregated growth data of Medellín shows that the institutional changes might have had positive developmental outcomes.

However, a closer look at the disaggregated data reveals that the composition of political, institutional and economic factors in Medellín's political settlement has incentivised economic growth driven by a large expansion of activities in sectors that are marked by low productivity (figures $\underline{3}$ and $\underline{4}$ ). While the value-added share of manufacturing industries has consistently decreased since 2005, the financial sector as well as hospitality services (tourism) and construction increased by large margins (figure 3). In fact, in 2014 these three economic sectors were responsible for over 50\% of value added and GDP growth (figure 4). The focus on developing a tourist industry is compatible with broader global economic transformation patterns elsewhere in Latin America (Robinson, 
2010). However, tourism depends on highly price- and income-elastic and unstable demand. In Medellín, despite authorities seeking ‘to sell the city’ in a very aggressive manner, as a host locality the local government has very little control over this demand and thus over possible labour market impacts.

The gap between manufacturing and non-manufacturing growth of GDP is widening. With valued-added growth of over 53\% between 2005 and 2014 the nonmanufacturing sectors have become the leading drivers of economic growth. While the manufacturing sector has experienced some growth, the sector has become increasingly marginalised as it now only contributes $11 \%$ to GDP growth (figure 4).

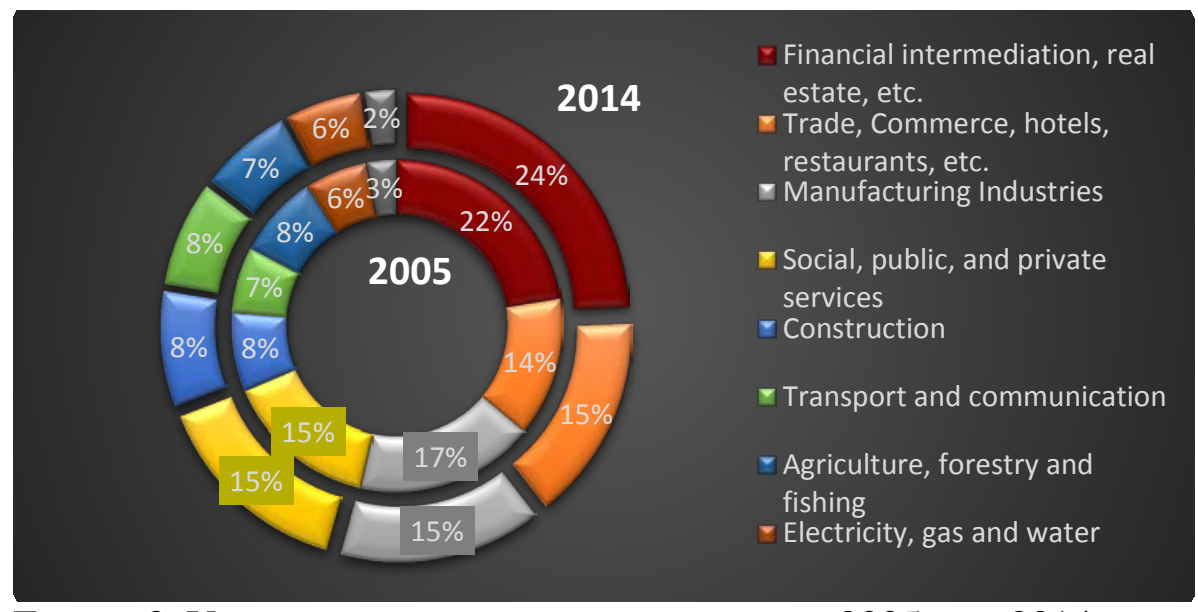

FIGURE 3: VALUE ADDED BY ECONOMIC SECTORS, 2005 AND 2014 SOURCES: CAMARA DE COMERCIO (2015), WITH DATA FROM DANE (2017)

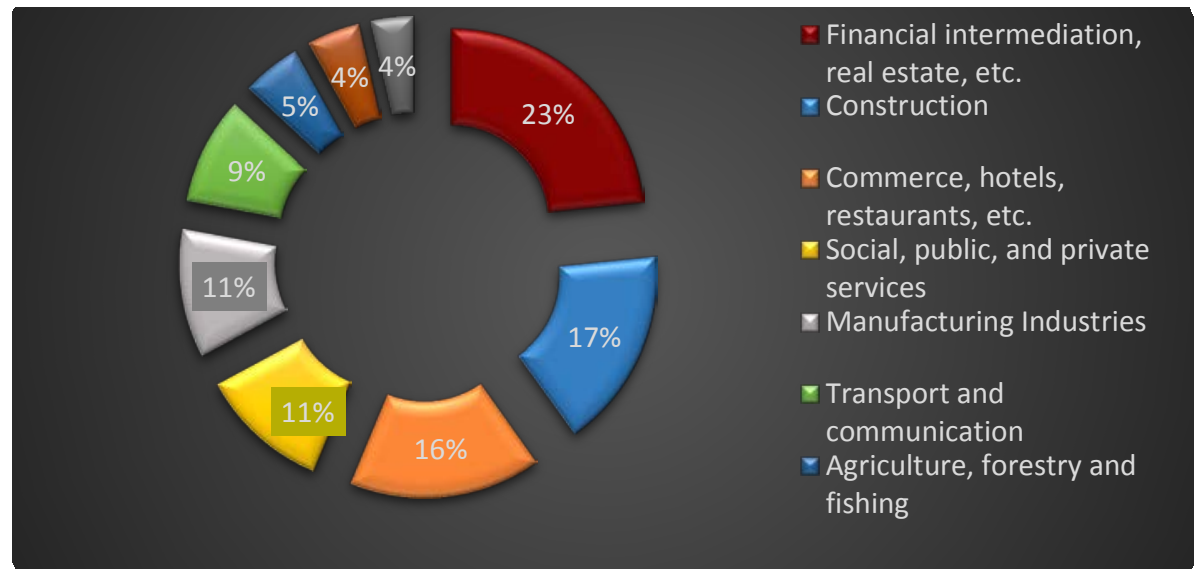

FIGURE 4: CONTRIBUTION TO GDP GROWTH BY ECONOMIC SECTOR, 2014 SOURCES: CAMARA DE COMERCIO (2015), WITH DATA FROM DANE (2017) 
Following Porter (2003) and Ramírez et al. (2014), who argue that regional productivity potential is determined by the presence of traded industries as well as the relative productivity of these industries, employment concentration and productivity growth of nonagricultural firms based in Medellín are analysed. The data are from different years of the Encuesta Anual Manufacturera (Annual Manufacturing Survey, EAM) as well as the Planilla Integrada de Liquidación de Aportes para Seguridad Social (Integrated Liquidation Accounts for Social Security, PILA) ${ }^{6}$.

More specifically, two factors that determine the entrepreneurial capacities of firms in Medellín to achieve growth high productivity sectors are studied. Firstly, Employment Concentration Factor (ECF) is calculated, which provides insight into the concentration of employment in each sector in Medellín relative to similar activities in other parts of the country. ECF shows the relation of local employment in a specific sector in Medellín $\left(\mathrm{e}_{\mathrm{sM}}\right)$ with the total employment of Medellín ( $\mathrm{e}_{\mathrm{M}}$ ), divided by the relationship between national employment in that sector $\left(\mathrm{E}_{\mathrm{sT}}\right)$ and total employment nationally $\left(\mathrm{E}_{\mathrm{T}}\right)$.

$$
E C F_{S M}=\frac{\left(\frac{e_{S M}}{e_{M}}\right)}{\left(\frac{E_{S T}}{E_{T}}\right)}
$$

An $\mathrm{ECF}_{\mathrm{sM}}>1$ means that a specific industry is concentrated in Medellín, relative to the rest of the country. Following the rationale of Porter (2003) and Ramírez et al. (2014), the relative employment concentration of a local sector can indicate the traded capacities of that sector. An $\mathrm{ECF}_{\mathrm{SM}}=1$ or $<1$ shows that economic activities of the analyzed sector are geared towards local market needs and can be described as 'local sectors' (see Ramírez et al., 2014). 
The second variable for the analysis of Medellín’s non-agricultural firms is the Labour Productivity Factor (LPF), which serves as a proxy for Medellín’s productivity performance. The model proposed by Ramírez et al. (2014: 25) can help determining this proxy for relative productivity of local and tradable industries. This model estimates the LPF variable by comparing the salaries of workers in a particular sector of Medellín’s industry with the average salary that is paid across Medellín's economy ( $\left.\mathrm{LPF}_{1}\right)$. With the assumption that workers that have higher skills in higher productivity sectors are better remunerated than low-skilled workers in sectors with lower productivity, this variable can help in determining relative regional productivity of a particular sector ${ }^{7}$.

$$
L P F_{1}=\frac{\text { Salary }_{S M}}{\operatorname{Salary}_{M}}
$$

Depending on data availability, LPF is calculated comparing the salaries of a particular industrial sector in Medellín with the average salary paid in that sector nationally $\left(\mathrm{LPF}_{2}\right)$.

$$
L P F_{2}=\frac{\text { Salary }_{S M}}{\operatorname{Salary}_{S T}}
$$

Due to limited availability of data on salaries in the EAM data, LPF calculations show the relationship between value added per worker in a particular industrial sector of Medellín with value added per worker in the entire local economy $\left(\mathrm{LPF}_{3}\right)$. Or value added per worker in a specific local industry over value added per worker in that industry on the national level $\left(\mathrm{LPF}_{4}\right)$.

$$
\begin{aligned}
& L P F_{3}=\frac{\text { Value Added }_{S M}}{\text { Value Added }} \text { A } \\
& L P F_{4}=\frac{\text { Value Added }}{s M} \\
& \text { Value Added } \\
& s T
\end{aligned}
$$


The findings for Medellín show that there is a large absence of tradable and high productivity economic activities. The only tradable sector that shows high productivity potential and concentrates more than 10,000 employees is Medellín’s financial sector. This underlines the trend of the finance-driven and possibly speculative development of the city's economy. The PILA data also reveals that the tradable industries of textile, metal and plastic show low productivity capabilities in relation to other economic activities, while at the same time these sectors concentrate a large proportion of local employment (see figure 5). The relatively high productivity of the electricity, gas and water sector can be explained by the presence of EPM and its role as one of Colombia's largest utility providers.

However, most economic activities are concentrated in the low LPF and low ECF quadrant (see figure 5). The low productivity and the lack of trading capacities of these sectors clearly indicates that economic growth in Medellín over the past decade or so is largely built on weak foundations.

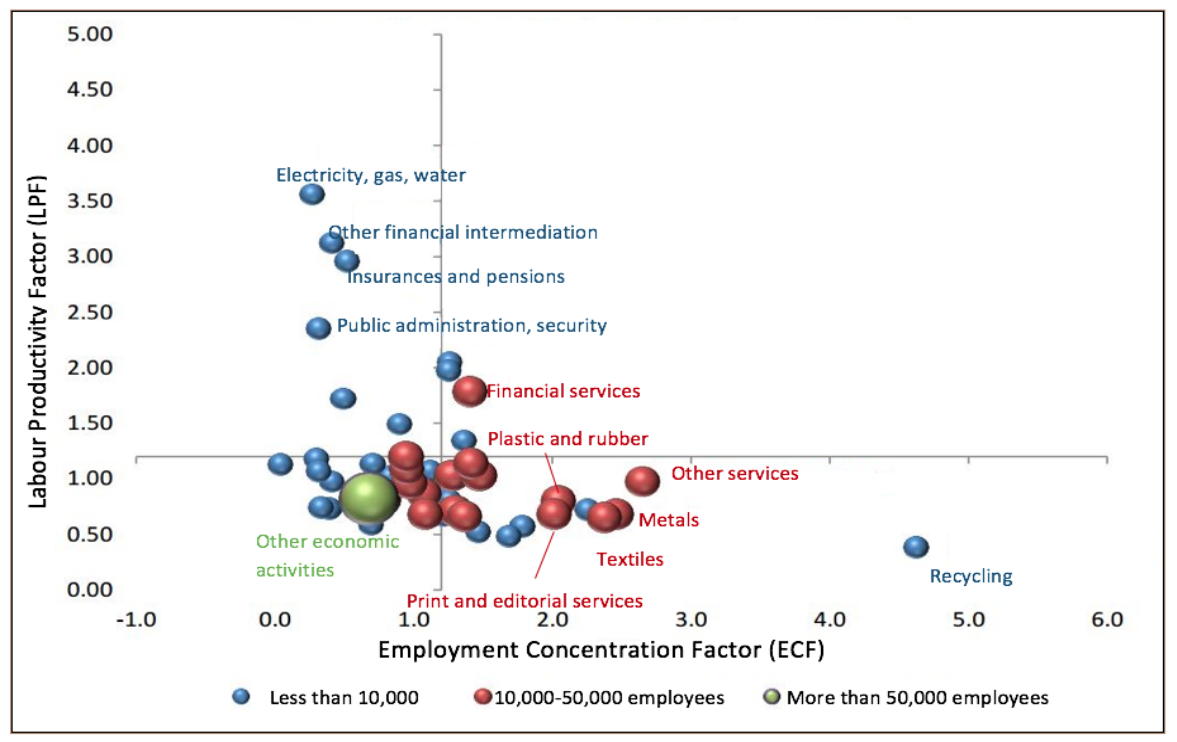

FIGURE 5: EMPLOYMENT CONCENTRATION AND PRODUCTIVITY OF SECTORS IN MEDELLÍN SOURCE: RAMÍREZ ET AL. (2014), WITH DATA FROM PILA 
Medellín’s industry is dominated by labour-intensive manufacturing of non-durable goods, such as textile and furniture (see figure 6). Most employment is concentrated in these sectors, where ECF is relatively high. However, these sectors have low productivity capabilities. This becomes visible in figure 6 , where the low productivity of these sectors is measured by the generation of value added per worker in comparison to general economic activities in industrial sectors of Medellín’s economy. The only non-agricultural sector that shows high productivity capabilities is the beverage industry, which at the same time seems to be concentrated on local markets. The inward relationship between ECF and LPF depicted in figure 6 clearly shows that sectors marked by high productivity in Medellín are limited to the local economy and do not concentrate large parts of the labour force.

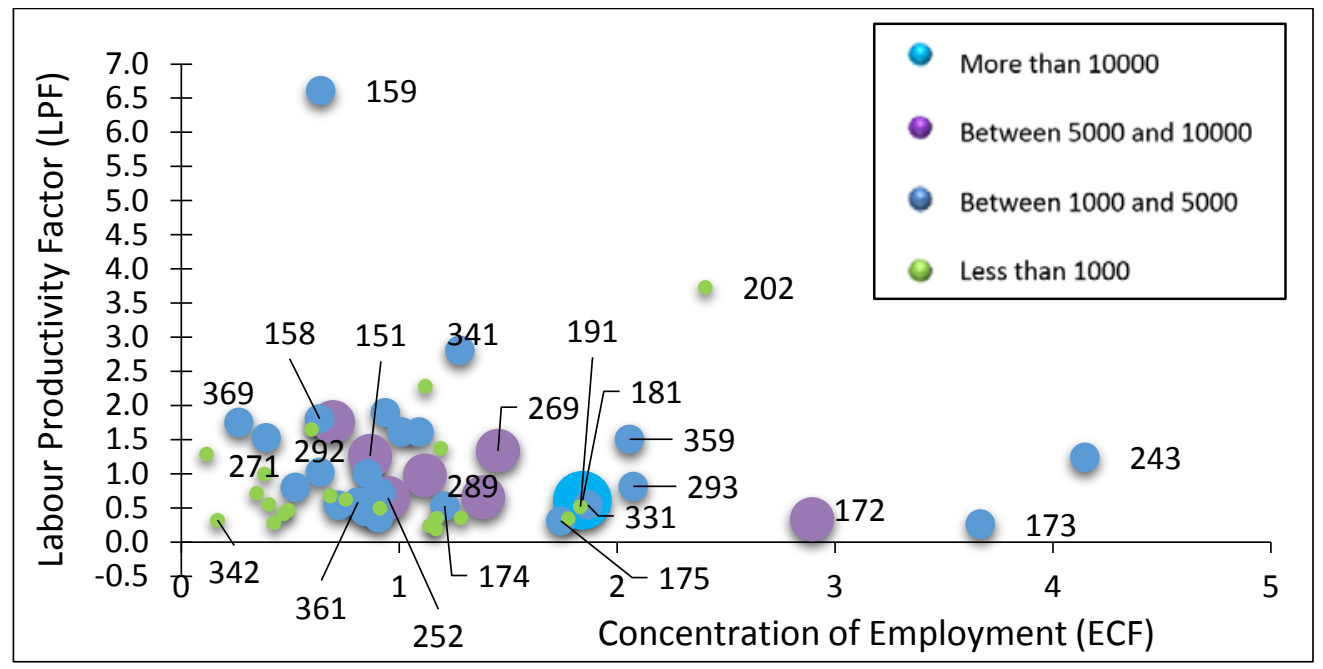

FIGURE 6: EMPLOYMENT CONCENTRATION AND PRODUCTIVITY: MANUFACTURING INDUSTRY SOURCE: DATA FROM EAM ${ }^{\mathbf{8}}$, OWN CALCULATION

The trend of Medellín’s low productivity growth is also reflected in urban labour market developments. In figure 7, negative or at least questionable trends of Medellín’s labour market become visible. Compared to the rest of the country, the overall number of established companies increased, while value added and gross production of Medellín’s 
economy decreased. Figure 7 furthermore shows that the increase in employment was largely absorbed by an increase in temporal employees, while real wages (income) and permanent employment stagnated or even decreased. The increase of temporal employees is also an indicator of the continued prominence of informal employment in Medellín, which often reinforces tendencies of low wage and flexible formal labour market. It is thus unsurprising that Medellín has on of the lowest GDP per capita in Latin America (see Brookings, 2015).

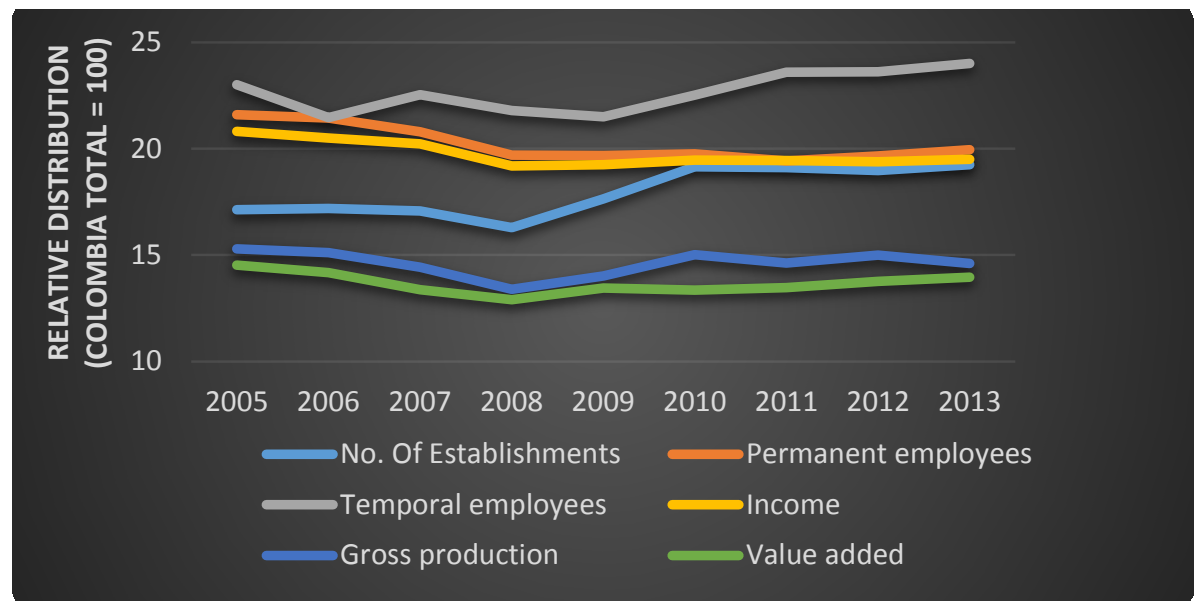

FIGURE 7: RELATIVE DISTRIBUTION OF MEDELLÍN’S LABOUR MARKET VARIABLES SOURCE: DANE (2017), OWN CALCULATIONS

To gain further insights into the characteristics and productivity capacities of Medellín’s economy, a closer look at the relationship between the local gross employment elasticities and the development of labour productivity is advisable. Gross employment elasticity is defined as the ratio between employment growth and GDP growth. The degree of employment elasticity of a country (or in this case a city) is indicative of the degree of flexibility of the national (or local) labour market. A higher elasticity indicates a higher degree of labour market flexibility. 
General trends in Latin America show that employment elasticities are much higher than in the rest of the world (Palma, (2011). The labour market of Colombia in general and Medellín in particular is not an exception to this. Quite the contrary: Cano and Ochoa (2008) as well as Vélez Cardona (2001) find that Medellín has very high gross employment elasticities resulting from the relatively high sensitivity of Medellín’s employment to output growth. The particularities of Medellín’s labour market, characterised by its structurally low productivity and high gross employment elasticities, often limit the amount of productivity growth and high-wage employment that can be generated with additional GDP growth. The highly flexible labour market regime in Medellín - reinforced through lowwage policies and the continued prominence of informal employment - undermines potential productivity growth in periods of high economic dynamism. In such periods, additional growth is absorbed by an increase in employment.

Overall, these trends explain why much of the formal sector of Medellín’s economy remains in such activities that require low technology and low-skilled labour. Palma’s (2011: 29) conclusion for Latin America aligns closely with the findings for Medellín: 'In other words, this bulk of the economy can operate with few compulsions for productivity growth thanks to 'flexible' labour markets,... and a (typically) high degree of oligopolistic concentration'. The modern sector of Medellín is thus based on low productivity manufacturing of non-durable commodities, a low technology service sector that has low productivity growth rates, and the abundance of cheap (informal) labour supply. It is therefore not surprising that Medellín remains the most unequal city in one of the most unequal countries worldwide (see figure 8). 


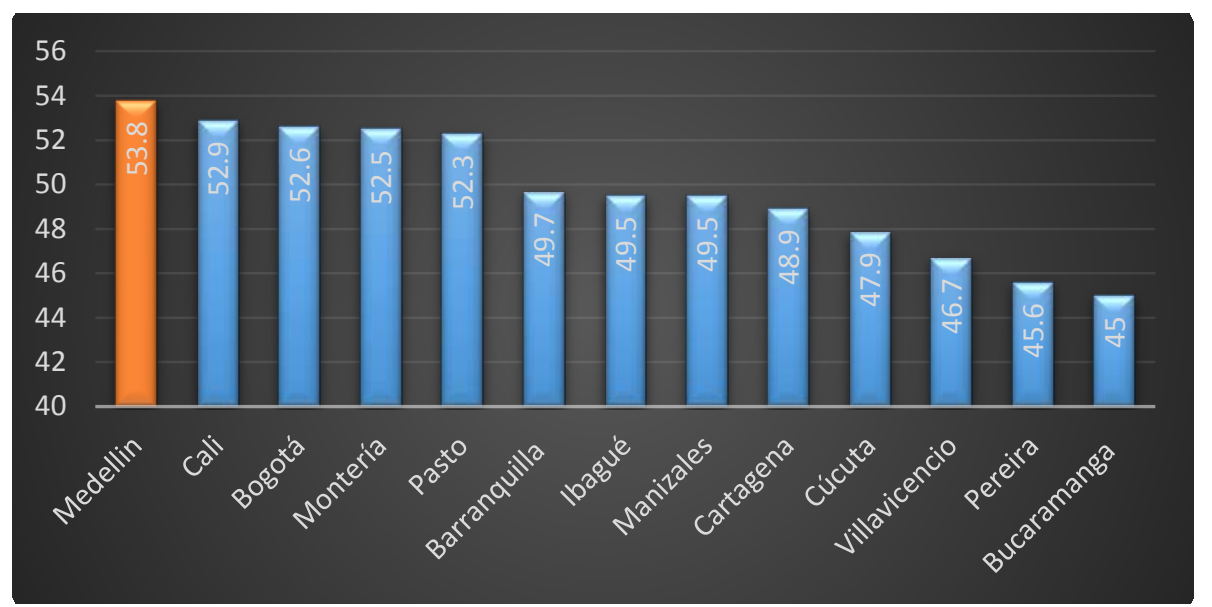

FIGURE 8: INEQUALITY IN MAJOR COLOMBIAN CITIES, GINI LEVELS FOR 2010 SOURCE: DANE (2017), OWN ELABORATION

The implementation of a particular brand of governance reforms in Medellín that have largely incorporated neoliberal ideas has not only hindered the creation of opportunities for high productivity growth, but has also crippled possibilities of creating market compulsions in which these opportunities can be taken up. Furthermore, the very particularity of Medellín’s economy is that it has served as a very effective tool for the transnationalised capitalist elite to perpetuate structural tendencies of unequal distributional outcomes in the city's society. The hegemonic nature of the organisational power of actors that promote market-driven development makes it close to impossible actors external to the current ruling coalition to challenge this strategy.

\section{Conclusion}

This article has argued that the distribution of power in Medellín and the evolving elite interests have shaped governance structures in ways which not only provide the economic elite of the GEA access to sources of power (i.e. transnational capital and EPM profits) that help in sustaining power balances, but also contribute to low productivity development outcomes. The local governance reforms implemented in Medellín since 2003 need to be 
understood as opportunistic institutional mechanisms to deepen powers of a transnationalised capitalist elite, adopted in the larger neoliberal context of Colombia's polity.

The analysis of qualitative and quantitative empirical data showed how the establishment of institutional mechanisms enhanced conditions in which policy strategies are targeting low productivity sectors with perceived comparative advantages in transnational capitalist chains of value creation. Medellín’s governance agenda has achieved neither necessary nor sufficient conditions for generating positive forward and backward linkages for productivity growth of local firms as they effectively contributed to the expansion of service-based accumulation.

These developmental outcomes underline Medellín’s return to static comparative advantages in labour-intensive industries and low technology services. Medellín’s governance model does not challenge but rather perpetuates the city’s productivity and inequality problems.

Unless structural reforms targeting low wages, tackling informality and incentivising firms to become competitive through the development of technological capabilities are implemented, these tendencies are likely to persist. Future contributions to the discussion on Medellín’s development need to focuses on specific policy alternatives to raise local productivity levels. This could provide national and local governance agencies with important insights on how to achieve more inclusive and sustainable productivity growth. Furthermore, future empirical research will have to unpack existing and potential local productivity growth opportunities through forward and backward linkages to other sectors and regions as well as to transnational capital. 


\section{Notes}

${ }^{1}$ Due to the nature of the illicit drug economy, it is clos to impossible to predict the exact economic power of this industry. Holmes et al. (2010) and Franz (2016) make interesting estimations for the influence of the illicit economy on the national economy. Moncada (2016), Duncan (2013) and Salazar (2012) argue that a sizable amount of Medellín’s economic activities depend on the income flows of the drug industry. Particularly the sectors of construction and finance are believed to be the main beneficiaries of illicit drug income.

2 The GEA is a conglomerate with a cross-share ownership structure led by the finance and insurance company Suramericana de Seguros (Sura), its subsidiary bank Bancolombia, the cement producer Argos, and the food processor Nutresa. Today, the GEA controls companies in Medellín that make up for around 80\% of the city’s GDP and contributes around $8 \%$ to Colombia’s GDP. Measured by market valorisation, Bancolombia is Colombia's third largest company, while Sura is ranked number four, Argos follows on rank six, Nutresa is ranked ninth. Together, these core companies have a market valorisation of over 26 billion Pounds Sterling (in 2014 constant GBP). Their combined market valorisation makes up for around $25 \%$ of the value of all publically traded companies in Colombia (Fradique-Méndez, 2014). As such, the GEA reflects the current formation of Medellín’s economy. The GEA also presents an insightful case that shows how local and regional traditions (regionalismo) play an important role in the way in which the economic and political powers are distributed in Colombia’s society.

${ }^{3}$ While Colombia's traditionally centralised policy regime constrains local agencies in their decision making, there exist a verity of different mechanisms through which local 
governments can engage in active economic policymaking. Decentralisation reforms, such as the changes to the management of locally owned public utility provider in 1994 and 1998, have increased the economic policy influence of local governments (see Furlong, 2015).

${ }^{4}$ These developments closely correspond to general trends of increased corporate debt in less developed countries since 2008. Some observers find links between these developments and the Quantitative Easing (QE) policy of the US Federal Reserve, implemented between 2008 and 2014. QE provided longer-term private sector credits at low interest rates, which aimed at incentivising private investment for the recovery of postcrisis developed economies. However, the majority of the funds - after being leveraged by hedge funds - resulted in an expansion of debt on corporate balance sheets in less developed countries. Analysing the links between this policy and dollar credit, McCauley et al. (2015) find that between 2009 and 2014 bonds and bank loans to non-bank borrowers outside of the US increased from US\$6 trillion to US\$9 trillion. Palma (2015) finds that for Latin America, this flood of cheap US dollar credits had negative impacts for the balance sheets of non-bank corporations.

5 The Compromiso Ciudadano, founded in 2001 by Sergio Fajardo and Alonso Salazar, is a coalition of NGO representatives, academics, the business sector, and the media that 'focused on how to translate their frustration with Medellín’s political class into action’ (Fajardo and Andrews, 2014: 4). Sergio Fajardo has been at the head of this political movement focusing on institutional reforms in order to overcome the 'bastion of old-style policy making’ (Devlin and Chaskel, 2010: 3). 
${ }^{6}$ The access to PILA data is restricted. Available data was taken from Ramírez et al. (2014).

${ }^{7}$ This article recognises that there are several problems with equating average salary or average value added per worker in a particular industrial sector with the productivity performance of that sector. For example, price distortions caused by market power of a firm in a particular sector can affect wages in ways that have little relation to changes in productivity. However, the variable LFP reflects the most accurate and valid proxy for local productivity performance available, also given the limited availability of data for the case of Medellín.

${ }^{8}$ Classification codes: 151: Production and procession of meat and fish; 158: Other foodstuff; 159: Beverages; 172: Weaving of textiles; 173: Finishing of textiles; 174: Other textile products; 175: Textile and knitwear; 181: Wearing apparel, except fur; 191: Leather; 202: Veneer sheets; 243: Millwood, Veneer, Plywood, and Structural Wood Members; 252: Rubber products; 271: Basic iron and steel; 289: Fabricated metal products and service activities related to metalworking; 292: Machinery of special purpose; 293: Household appliances; 331: Medical appliances; 341: Manufacture of paper and paper products; 342: Printing, publishing and allied industries; 359: Other transportation equipment; 361: Furniture; 369: Other manufacturing industries. 
This is the accepted manuscript of an article published by SAGE in Local Economy: The Journal of the Local Economy Policy Unit available online: https://doi.org/10.1177/0269094218755560

Accepted version downloaded from SOAS Research Online: https://eprints.soas.ac.uk/31772/

\section{References}

Abdulai A-G (2017) Rethinking Spatial Inequality in Development: The Primacy of Power Relations. Journal of International Development 29(3): 386-403.

Acemoglu D and Robinson J (2012) Why Nations Fail: The Origins of Power, Prosperity, and Poverty. New York: Crown Publishing Group.

Acemoglu D and Robinson J (2013) Economics versus Politics: Pitfalls of Policy Advice. Journal of Economic Perspectives 27(2): 173-192.

Acemoglu D, Johnson S and Robinson J (2004) Institutions as the Fundamental Cause of Long-Run Growth. Working Paper, Cambridge Mass.: National Bureau of Economic Research.

Alcaldía de Medellín (2004) Plan de Desarrollo 2004-2007: Medellín, compromiso de toda la ciudadanía. Medellín: Alcaldía de Medellín.

Alcaldía de Medellín (2008) Plan de Desarrollo 2008-2011: Medellín Es Solidaria y Competitiva. Medellín: Alcaldía de Medellín.

Alonso M, Giraldo J and Sierra D (2007) Medellín: El complejo camino de la competencia armada. In: Romero M (ed.), Parapolítica. La ruta de la expansión paramilitar y los acuerdos políticos, Bogotá: Cooperación Nuevo Arco Iris, pp. 109-164.

Bahl V (2012) Murder Capital to Modern Miracle? The Progression of Governance in Medellín, Colombia. DPU Working Paper 143.

Baldwin R (2013) Global supply chains: why they emerged, why they matter, and where they are going. In: Global value chains in a changing world, Geneva: Fung Global Institute (FGI), Nanyang Technological University (NTU), and World Trade Organization (WTO), pp. 13-59.

Ballvé T (2013) Grassroots masquerades: Development, paramilitaries, and land laundering in Colombia. Geoforum 50: 62-75.

Behuria P, Buur L and Gray H (2017) Studying political settlements in Africa. African Affairs: 1-18.

Betancur MS (2008) ¿Desarrollo e Innovación para quien? Una mirada criticopropositiva a la línea tres del plan de desarrollo de Medellín 2008-2011. Instituto Popular de Capacitación - IPC Mayo 2008.

Betancur MS, Stienen Á and Urán Arenas OA (2001) Globalización: cadenas productivas \& redes de acción colectiva: configuración territorial y nuevas 
formas de pobreza y riqueza en Medellín y el Valle de Aburrá. Medellín; Bogota: Tercer Mundo.

Biglaiser G (2002) Guardians of the Nation: Economists, Generals, and Economic Reform in Latin America. Notre Dame: University of Notre Dame Press.

Bojanini DE (2014) Interview with David Bojanini.

Bonilla C and Amado R (2013) Perfil histórico de las Empresas Públicas de Medellín (EPM): Datos historicos. University of Montreal.

Bonilla C, Carranza S and Furlong K (2013) Perfil Histórico de Empresas Públicas de Medellín (EPM): Presentación de la base de datos. Montreal: Universidad de Montreal. Departamento de Geografía.

Botero F and Villegas LJ (2005) Historia de Empresas Públicas de Medellín. Revista Empresas Públicas 15(4).

Brand P (2013) Governing inequality in the South through the Barcelona model: 'social urbanism' in Medellín, Colombia. Interrogating Urban Crisis: Governance, Contestation, Critique, Leicester: De Montfort University. Available from: http://www.dmu.ac.uk/documents/business-and-lawdocuments/research/lgru/peterbrand.pdf (accessed 8 July 2014).

Brenner N and Theodore N (2002) Cities and Geographies of 'Actually Existing Neoliberalism'. Antipode 34(3): 349-379.

Brookings (2015) Global Metro Monitor: An Uncertain Recovery. Washington, D.C.: The Brookings Institute. Available from: http://www.brookings.edu/ /media/Research/Files/Reports/2015/01/22-globalmetro-monitor/bmpp_GMM_final.pdf?la=en (accessed 5 October 2015).

Cabrera C and Naranjo R (2003) Cabrera Saavedra, Carlos y Naranjo Galves, Rodrigo (2003). Las leyes de saneamiento fiscal y sus efectos sobre la descentralización”'. In: Becker, Alejandro; Chica, Carolina y Cárdenas, Miguel (eds.) Ordenamiento territorial. Reivindicación de la descentralización para el desarrollo, Bogotá, GTZ-FESCOL. In: Becker A, Chica C, and Cárdenas M (eds), Ordenamiento territorial. Reivindicación de la descentralización para el desarrollo, Bogotá: GTZ-FESCOL.

Cámera de Comercio (1995) La Ventaja competitiva de Medellín. Informe Monitor. Medellín: Cámera de Comercio de Medellín para Antioquia. Available from: http://www.camaramedellin.com.co/site/Portals/0/Documentos/Biblioteca/compet itividad/ventaja-competitiva-medellin-monitor.pdf (accessed 4 April 2014).

Cámera de Comercio (1999) Plan Estratégico de Medellín y el Área Metropolitana 2015. Medellín: Cámera de Comercio de Medellín para Antioquia. 
Cámera de Comercio (2011) Plan Regional de Competitividad 2011. Medellín: Cámera de Comercio de Medellín para Antioquia. Available from:

http://www.camaramedellin.com.co/site/Portals/0/Documentos/Biblioteca/Resum en_Ejecutivo_PRC.pdf (accessed 9 May 2015).

Cámera de Comercio (2015) Desempeño de la economía de Antioquia 2014/2015: evolución por sectores. Medellín: Camera de Comercio de Medellin para Antioquia. Available from: http://www.camaramedellin.com.co/site/Portals/0/Documentos/RUEDA\%20DE\% 20PRENSA\%20-\%20MARZO\%203\%20DE\%202015\%20-\%20Coyuntura.pdf. (accessed 5 July 2016).

Cano CA and Ochoa AM (2008) Empleo, desempleo y salario real: análisis del mercado laboral de la ciudad de Medellín (1995-2006). Lecturas de Economia 69(JulioDiciembre): 117-139.

Carranza S and Bonilla C (2013) Perfil histórico de las Empresas Públicas de Medellín (EPM): Datos financieros. University of Montreal.

Carvajal Y (2011) La Participación Ciudadana en Medelín, Una Reflexión a Manera de Balance. Grupo de Estudios en Ciencia Política y Administración Pública. Available from: http://gecipap.blogspot.com/2013/09/1-la-participacionciudadana-en.html (accessed 5 September 2012).

Constitución Política de Colombia (1991) Constitución Política de Colombia 1991. Senado de Colombia.

DANE (2017) Catálogo Central de Datos. Database. Available from: https://formularios.dane.gov.co/Anda_4_1/index.php/catalog (accessed 26 March 2016).

Devlin M and Chaskel S (2010) From Fear to Hope in Colombia: Sergio Fajardo and Medellín, 2004-2007. Innovations for Successful Societies, Princeton University. Available from: http://www.princeton.edu/successfulsocieties (accessed 2 May 2013).

Di John J and Putzel J (2009) Political Settlements: Issues Paper. Birmingham: Governance and Social Development Resource Centre (GSDRC). Available from: https://core.ac.uk/download/files/119/103642.pdf (accessed 10 July 2011).

Dover R and Ocampo GI (2006) Del Estado privado al neoestatismo: el caso de Empresas Públicas de Medellín como aproximación a las relaciones entre Estado, empresa y política. In: Fernán G and Ocampo GI (eds), Globalización, cultura y poder en Colombia: una mirada interdisciplinaria, Medellín: La Carreta, pp. 251-289.

Duncan G (2005) Del Campo a la Ciudad en Colombia. La Infiltración Urbana de los Señores de la Guerra. Documento CEDE 2005(2). 
Duncan G (2013) Una Lectura Política de Pablo Escobar. Co-herencia 10(19): 235-262.

Duque Daza J (2007) Los partidos políticos colombianos 1974-2006:

Subinstitucionalización de los partidos tradicionales y emergencia de organizaciones políticas alternativas. Informe final del concurso: Partidos, movimientos y alternativas políticas en América Latina y el Caribe, Buenos Aires: CLACSO. Available from: http://bibliotecavirtual.clacso.org.ar/ar/libros/becas/semi/2004/partidos/duque.pdf (accessed 31 December 2013).

Escobar Arango D (2014) Interview with David Escobar Arango.

Escobar LF and Hoyos S (1986) Exportaciones industriales antioqueñas 1970-1983: un análisis de sus determinantes. Revista Antioqueña de Economía y Desarrollo 20: 54-63.

Fajardo A and Andrews M (2014) Does successful governance require heroes? The case of Sergio Fajardo and the city of Medellín: A reform case for instruction. WIDER Working Paper 2014(035).

Fernández Jilberto AE and Hogenboom B (2004) Conglomerates and Economic Groups in Neoliberal Latin America. Journal of Developing Societies 20(3-4): 149-171.

Fradique-Méndez C (2014) Guía del Mercado de Valores. Bogotá: Bolsa de Valores de Colombia. Available from:

http://www.valoresbancolombia.com/cs/Satellite?blobcol=urldata\&blobheaderna me1=content-type\&blobheadername2=Content-

Disposition\&blobheadername3=MDT-

Type\&blobheadervalue1=application\%2Fpdf\&blobheadervalue2=inline\%3B+file name\%3Dmyfile\&blobheadervalue3=abinary\%253B\%2Bcharset\%253DUTF8\&blobkey=id\&blobtable=MungoBlobs\&blobwhere=1266524247639\&ssbinary= true (accessed 5 February 2015).

Franco Restrepo VL (2005) Poder regional y proyecto hegemónico: el caso de la ciudad metropolitana de Medellín y su entorno regional 1970-2000. Medellin: Instituto Popular de Capacitacion -IPC-

Franz T (2016) Plan Colombia: illegal drugs, economic development and counterinsurgency - a political economy analysis of Colombia's failed war. Development Policy Review 34(4): 563-591.

Franz T (2017) Urban Governance and Economic Development in Medellín. Latin American Perspectives 44(2): 52-70.

Fukuyama F and Colby S (2011) Half a Miracle. Foreign Policy. Available from: http://www.foreignpolicy.com/articles/2011/04/25/half_a_miracle (accessed 22 July 2013). 
Furlong K (2015) Water and the entrepreneurial city: The territorial expansion of public utility companies from Colombia and the Netherlands. Geoforum 58(2015): 195207.

Garay LJ (1998) Colombia: estructura industrial e internacionalización 1967-1996. Bogota: Departamento Nacional de Planeacion.

Giustozzi A (2011) Art of Coercion: The Primitive Accumulation and Management of Coercive Power. Oxford: Oxford University Press.

Glassman J and Carmody P (2001) Structural adjustment in East and Southeast Asia: lessons from Latin America. Geoforum 32(1): 77-90.

Gómez CJL, Sánchez-Ayala L and Vargas GA (2015) Armed conflict, land grabs and primitive accumulation in Colombia: micro processes, macro trends and the puzzles in between. The Journal of Peasant Studies 42(2): 255-274.

Gutiérrez F, Pinto M, Arenas JC, et al. (2013) The Importance of Political Coalitions in the Successful Reduction of Violence in Colombian Cities. Urban Studies 50(15): $1-18$.

Hambleton R (2015) Power, place and the New Civic Leadership. Local Economy 30(2): 167-172.

Harvey D (2003) The New Imperialism. Oxford: Oxford University Press.

Hirschman AO (1981) Essays in Trespassing: Economics to Politics and Beyond. Cambridge: Cambridge University Press.

Holmes J, Piñeres SA and Curtin K (2010) Guns, Drugs, and Development in Colombia. Austin: University of Texas Press.

Hylton F (2007) Medellín’s Makeover. New Left Review 44(March April 2007): 70-89.

Jessop B and Sum N-L (2000) An Entrepreneurial City in Action: Hong Kong's Emerging Strategies in and for (Inter)Urban Competition. Urban Studies November 2000(37): 2287-2313.

Kauffman D, Kraay A and Zoido-Lobatón P (1999) Governance Matters. World Bank Policy Working Paper, Washington D.C.: World Bank.

Khan M (1995) State Failure in Weak States: A Critique of New Institutionalist Explanations. In: Harriss J, Hunter J, and Lewis CM (eds), The New Institutional Economics and Third World Development, London: Routledge, pp. 71-86.

Khan M (2009) Governance Capabilities and the Property Rights Transition in Developing Countries. Research Paper Series on 'Growth-Enhancing Governance’, London: SOAS, University of London. Available from: 
http://eprints.soas.ac.uk/9966/1/Property-Transitions.pdf (accessed 1 October 2012).

Khan M (2010) Political Settlements and the Governance of Growth-Enhancing Institutions. Research Paper Series on 'Growth-Enhancing Governance', London: SOAS, University of London. Available from: http://eprints.soas.ac.uk/9968/1/Political_Settlements_internet.pdf (accessed 1 October 2012).

Khan M (2011) The Political Settlement and its Evolution in Bangladesh. London: SOAS, University of London. Available from: http://eprints.soas.ac.uk/12845/1/The_Political_Settlement_and_its_Evolution_in _Bangladesh.pdf (accessed 19 January 2013).

Khan M and Blankenburg S (2009) The Political Economy of Industrial Policy in Asia and Latin America, in: Cimoli, M., Dosi, G., Stiglitz, J. (Eds.), Industrial Policy and Development: The Political Economy of Capabilities Accumulation. Oxford University Press, Oxford, pp. 336-377.

Khan MH (2012) Governance during Social Transformations: Challenges for Africa. New Political Economy 17(5): 667-675.

Krueger A (1974) The Political Economy of the Rent-Seeking Society. American Economic Review 64(3): 291-303.

Leyva S (2014) ¿Crisis O Continuidad? Una Discusión Sobre El Poder En Medellín A Partir De La Década De 1970. Estudios Políticos 44(Enero-Junio): 115-138.

Londoño CF (2004) Grupo Empresarial Antioqueño. Evolución de Políticas y Estrategias, 1978-2002. Revista EIA 1: 47-62.

López JC (2005) La génesis de Empresas Públicas de Medellín: el camino de la autonomía. Revista Letras Jurídicas 10(1).

López Restrepo A (1995) Las etapas de la liberalización de la economía colombiana. Santiago de Chile: CEPAL. Available from: http://repositorio.cepal.org/handle/11362/9632 (accessed 2 February 2016).

Loveman B (1999) For la Patria: Politics and the Armed Forces in Latin America. Wilmington: Rowman \& Littlefield Publishers.

Maclean K (2014) The 'Medellín Miracle': The politics of crisis, elites and coalitions. The Developmental Leadership Program 24: 1-72.

Martin G (2014) Medellín: Tragedia y Resurreción - Mafia, Ciudad y Estado. Medellin: Planeta. 
McCauley RN, McGuire P and Sushko V (2015) Global dollar credit: links to US monetary policy and leverage. BIS Working Papers 483. Available from: http://www.bis.org/publ/work483.pdf (accessed 10 July 2016).

Moncada E (2016) Urban Violence, Political Economy, and Territorial Control: Insights from Medellín. Latin American Research Review 51(4): 225-248.

Mejía Martínez J (2014) Interview with Jorge Mejía Martínez.

Ocampo JA (1986) Crisis y política económica en Colombia, 1980-1985. In: Thorp R and Whitehead L (eds), La crisis de la deuda en América Latina, Bogotá: Siglo Veintiuno Editores, pp. 213-241.

Ocampo JA (2007) Historia económica de Colombia. Bogota: Planeta.

Palacios M (ed.) (2001) Presencia y ausencia de populismo: para un contrapunteo colombo-venezolano. In: De populistas, mandarines y violencias. Luchas por el poder, Bogotá: Planeta, pp. 45-81.

Palma JG (2011) Why has Productivity Growth Stagnated in Most Latin American Countries Since the Neo-Liberal Reforms? Cambridge Working Papers in Economics (CWPE) 1030. Available from: http://www.econ.cam.ac.uk/dae/repec/cam/pdf/cwpe1030.pdf (accessed 7 June 2013).

Palma JG (2015) Why corporations in developing countries are likely to be even more susceptible to the vicissitudes of international finance than their counterparts in the developed world: A Tribute to Ajit Singh. Cambridge Working Papers in Economics 1539. Available from: http://www.econ.cam.ac.uk/research/repec/cam/pdf/cwpe1539.pdf (accessed 10 July 2016).

Pérez Gutiérrez L (2003) Tarifas de energía justas. Semana, Bogotá. Available from: http://www.semana.com/opinion/articulo/tarifas-energia-justas/57533-3 (accessed 2 July 2014).

Pérez Moreno S (2014) Interview with Santiago Pérez Moreno.

Pérez Salazar IM (2014) Interview with Mauricio Pérez Salazar.

Porter M (2003) The Economic Performance of Regions. Regional Studies 36(6\&7): 549-578.

Pospisil J and Rocha Menocal A (2017) Why Political Settlements Matter: Navigating Inclusion in Processes of Institutional Transformation. Journal of International Development 29(5): 551-558. 
Ramírez Brouchoud MF (2012) Transformaciones del Estado en el gobierno local: La nueva gestión pública en Medellín. Reflexión Política Año 14(28 Diciembre): 8295.

Ramírez JM, Zubieta I and Bedoya JG (2014) Productividad y Competetividad del Sistema de Ciudades. Informes de Investigación, Bogotá: FEDESARROLLO Centro de Invesigación Económica y Social. Available from: http://www.repository.fedesarrollo.org.co/bitstream/11445/202/1/Productividad_S -de-C_Informe-Final.pdf (accessed 23 October 2014).

Restrepo Santamaría N (2011) Empresariado antioqueño y sociedad, 1940-2004. Influencia de las élites patronales de Antioquia en las políticas socioeconómicas colombianas. Medellín: Universidad de Antioquia.

Rettberg A (2005) Business Versus Business? Grupos and Organized Business in Colombia. Latin American Politics and Society 47(1): 31-54.

Reyes G (2003) Los dueños de América Latina: Cómo Amasaron sus Fortunas los Personajes más Ricos e Influyentes de la Región. Barcelona: Ediciones B.

Robinson WI (2010) Latin America and Global Capitalism - A Critical Globalization Perspective. Baltimore: John Hopkins University Press.

Rodrik D (1995) Trade Strategy, Investment, and Exports: Another Look at East Asia. NBER Working Papers 5339. Available from: http://www.nber.org/papers/w5339.pdf (accessed 12 September 2014).

Rodrik D (2014) When Ideas Trump Interests: Preferences, Worldviews, and Policy Innovations. Journal of Economic Perspectives 28(1): 189-208.

Romero M and Valencia L (eds) (2007) Parapolítica. La ruta de la expansión paramilitar y los acuerdos políticos. Bogotá: Cooperación Nuevo Arco Iris.

Salazar A (1990) No nacimos pa’ Semilla. Bogotá: CINEP.

Salazar A (2012) El Patrón del Mal. Doral, FL: Santillana USA.

Salazar A (2014) Interview with Alonso Salazar.

Sierra R (2014) Interview with Ricardo Sierra.

Steel G, Noorloos F van and Klaufus C (2017) The urban land debate in the global South: New avenues for research. Geoforum 83: 133-141.

Stiglitz J (1998) More Instruments and Broader Goals: Moving Toward the PostWashington Consensus. WIDER Annual Lecture 2. 
Thoumi F (1995) Political Economy and Illegal Drugs in Colombia. Boulder: Lynne Rienner.

Turok I (2014) The Seventh World Urban Forum in Medellín: Lessons for city transformation. Local Economy 29(6-7): 575-578.

Valderrama JD (2014) Interview with Juan David Valderrama.

Varela Barrios E (2010) Estrategias de expansión y modos de gestión en Empresas Públicas de Medellín, EPM. Estudios Políticos 36(Enero-Junio): 141-165.

Varela Barrios E (2011) Políticas y estrategias en la gestión de EPM- Medellín. Bogota: Ediciones De La U LTDA.

Vargas GA (2011) Drugs, Hearts and Minds: Irregular War and the Coca Economy in South Bolivar, Colombia (1996-2004). Civil Wars 13(1): 21-39.

Vélez Cardona RA (2001) El Mercado Laboral de Medellín: una aproximación teórica y empírica al funcionamiento del mercado y a la efectividad de las políticas de empleo sobre la demanda. Ecos de Economía 6(15): 10-23.

Vélez JA (2014) Interview with José Alberto Vélez.

Watt P and Zepeda R (2012) Drug War Mexico: Politics, Neoliberalism and Violence in the New Narcoeconomy. London and New York: Zed Books.

Williamson J (1990) Latin American Adjustment: How Much Has Happened? Washington D.C.: Institute for International Economics. 